\title{
Taxonomy of the Nacerdes (Xanthochroa) carniolica species-group from China (Coleoptera, Oedemeridae, Nacerdini)
}

\author{
Ying Tian', Guo-Dong Ren², Qiang Li' \\ I College of Plant Protection, Yunnan Agricultural University, Kunming 650201, China 2 College of Life \\ Sciences, Hebei University, Baoding 071002, China \\ Corresponding author: Guodong Ren (gdren@hbu.edu.cn; tianying_0727xy@163.com)
}

Academic editor: W. Schawaller | Received 7 March 2014 | Accepted 18 June 2014 | Published 17 July 2014

http://zoobank.org/ED33F86B-6276-4435-A52E-B689672ECDDE

Citation: Tian Y, Ren G-D, Li Q (2014) Taxonomy of the Nacerdes (Xanthochroa) carniolica species-group from China (Coleoptera, Oedemeridae, Nacerdini). ZooKeys 426: 111-118. doi: 10.3897/zookeys.426.7449

\begin{abstract}
This paper deals with a species-group carniolica of the genus Nacerdes from China. This species-group has seven known species/subspecies in the world and two of them are known from China. Nacerdes (Xanthochroa) arcuata sp. n. is a new species belonging to carniolica group. The species were collected from Anhui (Eastern China, 30 $\left.02^{\prime} 17.37^{\prime \prime} \mathrm{N}, 118^{\circ} 50^{\prime} 1.72^{\prime \prime} \mathrm{E}\right)$. A key to the species of the species-group from China is given along with a distribution map.
\end{abstract}

\section{Keywords}

Coleoptera, Oedemeridae, Nacerdes, taxonomy, new species, China

\section{Introduction}

The genus Nacerdes was erected by Dejean (1834) for Necydalis notata Fabricius, 1792 (= Cantharis melanura Linnaeus, 1758$)$ as the type species. More recent classifications were made by Arnett (1951, 1961), Švihla (1983, 1986, 1987, 1991, 1993, 1996, 1997 , 1998, 1999, 2001, 2004, 2005, 2006, 2008, 2009), Vázquez (1993, 2002, 2006), Allemand (1993) and Yoo et al. (2008). However, Švihla (1987, 1998, 2001, 2004, 2008) made the most significant progress in Nacerdes identification and taxonomy, he described 


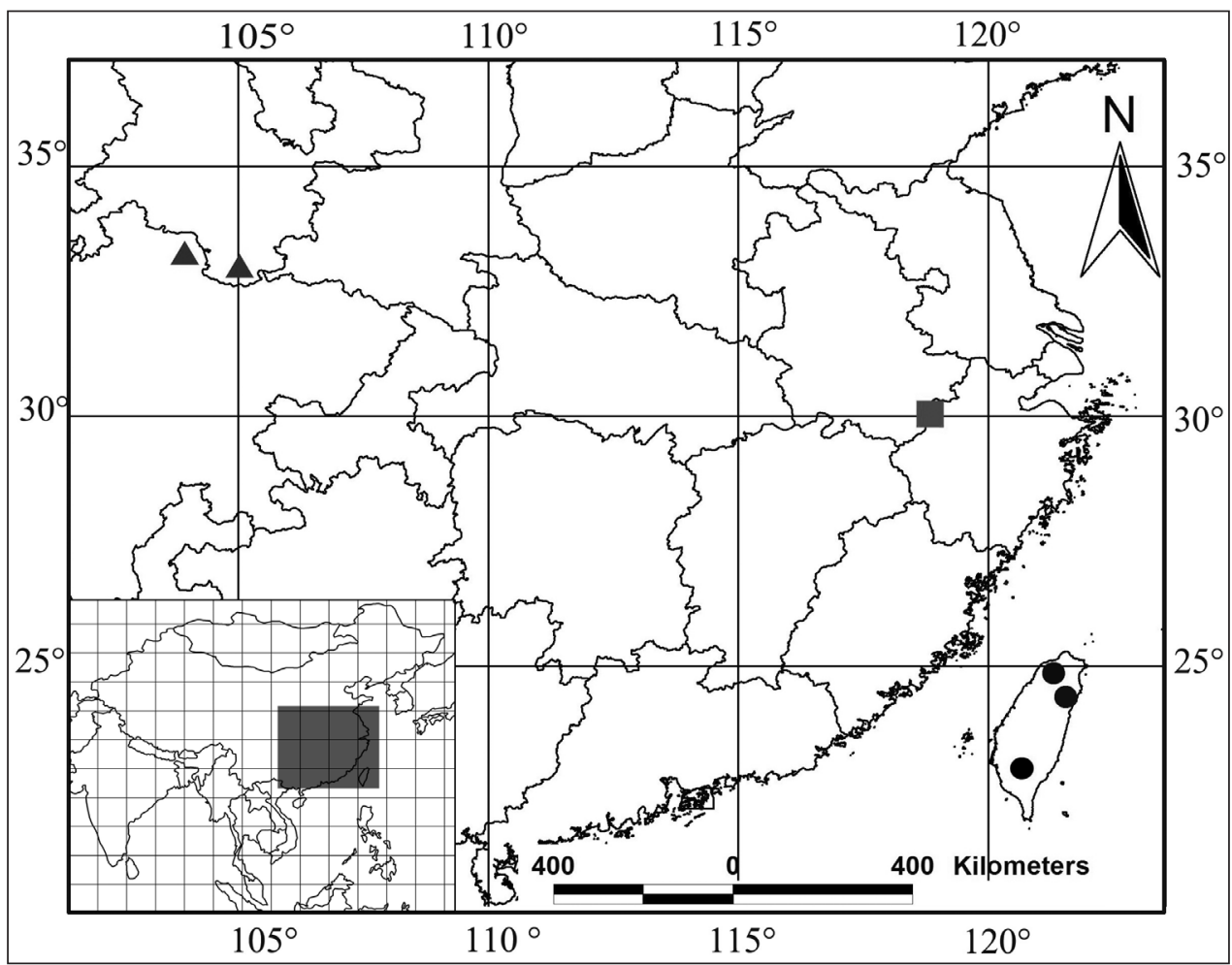

Figure I. Distribution of the Nacerdes (Xanthochroa) carniolica species-group from China. - $N$. (X.) hiromichii Švihla, 2004 A N. (X.) potanini Ganglbauer, 1890 - N. (X.) arcuata sp. n.

and recorded 22 Nacerdes species from China. Švihla (1998) divided the species of Western and Southern China and adjacent regions into six species-groups according to the shape of the aedeagus. Until now, the Nacerdes (Xanthochroa) carniolica species-group had seven species/subspecies (Švihla 1998, 2008), with two species known from China. In the present study, a new species of this group is described, an identification key to all known species of the Nacerdes (Xanthochroa) carniolica species-group from China is provided, and the distribution of the species-group is mapped (Fig. 1).

\section{Materials and methods}

\section{Collected material}

The beetles were collected by light trap from Anhui province, Eastern China region. Located across the basins of the Yangtze River and the Huai River, it borders Jiangsu to the east, Zhejiang to the southeast, Jiangxi to the south, Hubei to the southwest, Henan to the northwest, and Shandong for a tiny section in the north. 


\section{Material identification}

The collected specimens were identified based on a reference collection and key for species published by Švihla (1998).

\section{Examination and description}

The specimens were examined and described using a Nikon (SMZ800) dissecting microscope. Examinations of aedeagus were carried out. The aedeagus was dissected under a stereoscopic microscope, cleared in $5 \% \mathrm{NaOH}$ solution for eight minutes under water bath, then placed in a droplet of glycerol and examined under a compound light microscope. The measurements and photographs were carried out under a Leica (M205 A) dissecting microscope. A distribution map was prepared using the geographic information system software ARCVIEW GIS 3.2, based on the authors' database of the specimens examined for this study and those mentioned in the literature. Body length is measured from the anterior margin of the clypeus to the elytral apex, body width is measured across the humeral part of elytra. All measurements are in millimeters.

The terminology used in this paper largely follows Švihla (1998).

The holotype and paratypes are deposited in MHBU - Museum of Hebei University, Baoding, China.

\section{Taxonomy}

\section{Nacerdes (Xanthochroa) carniolica species-group}

Diagnosis. Apicale of aedeagus with recurrent angles, so that it is arrow-shaped in dorsal view.

Distribution. China (Anhui, Sichuan, Gansu, Taiwan), Northern Vietnam, Europe.

\section{Key to the species of Nacerdes (Xanthochroa) carniolica species-group from China} (Adapted from Švihla 1998)

$1 \quad$ Apex of elytra black 2

- $\quad$ Elytra brown with slight metallic green tinge N. (X.) potanini

2 Aedeagal apicale short, lateral view as in Fig. 12, abruptly narrowed apically in dorsal view (Fig. 13) N. (X.) biromichii

- Aedeagal apicale elongate, lateral view as in Fig. 10, gradually narrowed apically in dorsal view (Fig. 11) N. (X.) arcuata sp. n. 


\section{Nacerdes (Xanthochroa) arcuata sp. n.}

http://zoobank.org/0DB5A33D-0E46-4DE4-A339-4A529FDBF566

Figs $2-3,5-11$

Type material. Holotype: male (MHBU): China, Anhui Province, She County, Qingliangfeng N. R., alt. $320 \mathrm{~m}, 30^{\circ} 02^{\prime} 17.37^{\prime \prime N}, 118^{\circ} 50^{\prime} 1.72 " \mathrm{E}, 5-9 . v i .2013$, Ji-Shan Xu $\&$ Cai-Xia Yuan leg. Paratypes: $2 \hat{\jmath} \widehat{\partial}, 8$ 우 (MHBU), same data as holotype.

Diagnosis. This new species belongs to the $N$. $(X$.) carniolica species-group as defined by Švihla (1998) according to the shape of the aedeagus, it is similar to $N$. (X.) hiromichii Švihla, 2004, but can be distinguished from the latter by its smaller body, black head, basal $2 / 3$ of each femur saffron yellow, the rest of each leg sepia to black, and the different shape of aedeagal apicale.

Etymology. The specific name is derived from the Latin adjective arcuatus, meaning arched, referring to the characteristic shape of aedeagus in this species.

Description. Body length 10.3-12.7 mm, body width 2.1-2.7 mm. Head black, maxillary palpi sepia to black. Antennae black, antennomeres gradually lightening to sepia. Basal $2 / 3$ of femora saffron yellow, terminal portion of femora, tibiae and tarsi sepia to black. Pronotum, abdomen and elytra saffron yellow to terra-cotta, apex of each elytron black with dark blue metallic tinge.

Male (Fig. 2). Eyes large, protruding, head across eyes slightly wider than pronotum, frons between eyes 1.8 times as wide as length of antennomere II. Maxillary palp as in Fig. 5. Antennae slightly exceed 1/2 of elytral length, antennomere I more than twice as long as antennomere II, as long as antennomere III, dorsal surface of head and pronotum finely and sparsely punctate and yellow pubescence. Pronotum moderately longer than wide, slightly cordiform, both anterior and posterior pronotal depressions slightly to moderately developed, anterior margin straight, anterior corners rounded, lateral margins moderately sinuate, posterior corners obtuse, posterior margin moderately straight. Elytra nearly parallel-sided, matt, only their dark blue apex lustrous, elytra about four times longer than wide, elytral nervation developed. Both pygidium and last sternite subtriangular, pygidium rounded apically, last sternite incised to $2 / 3$ of its length as in Fig. 8, projections of urite VIII as in Fig. 6. Tegmen (Fig. 7) slightly longer than half of aedeagus, aedeagal apicale as in Figs 10-11.

Female (Fig. 3). Head across eyes as wide as pronotum, frons between eyes twice as wide as length of antennomere II, antennae almost reach elytral midlength, pronotum as long as wide, last abdominal segments as in Fig. 9.

Distribution. China: Anhui. 


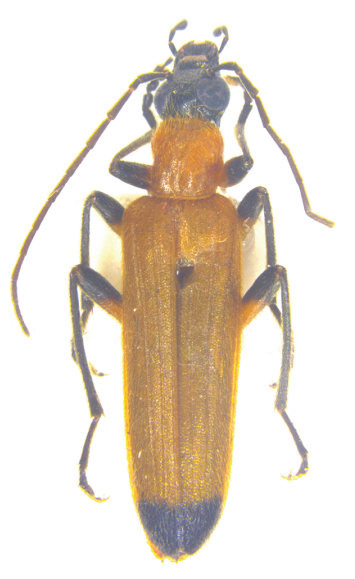

2

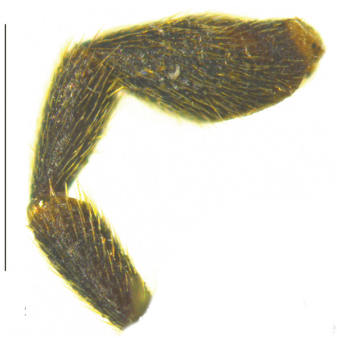

5

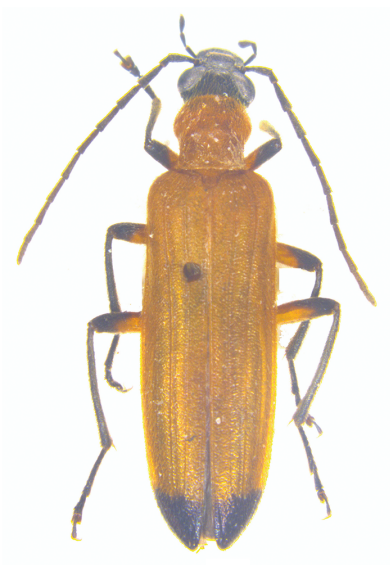

3

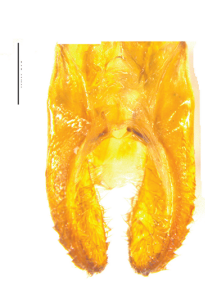

6

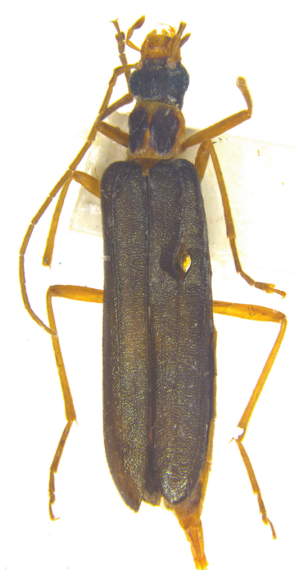

4

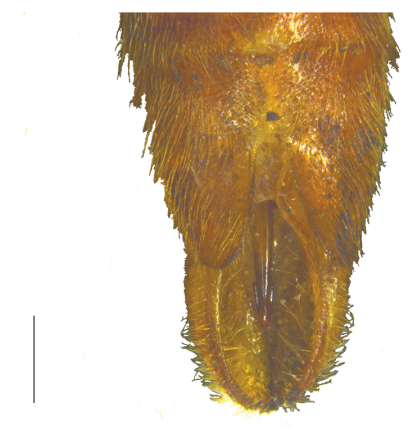

8

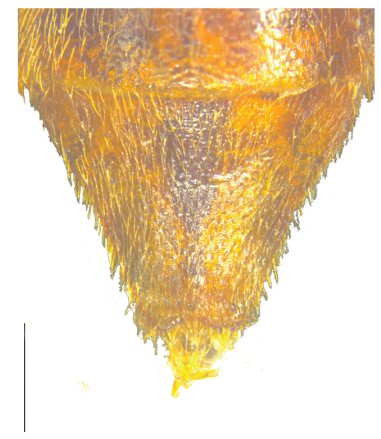

9

Figures 2-9. $N$. (X.) arcuata sp. n. (2-3, 5-9) and $N$. (X.) potanini (4). 2 Habitus, male 3 Habitus, female 4 Habitus, female 5 Maxillary palp 6 Projections of urite VIII 7 Tegmen in dorsal view 8 Last sternite, male 9 Last sternite, female. Scale bars $=0.5 \mathrm{~mm}$. 


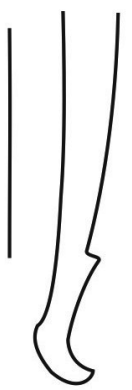

10

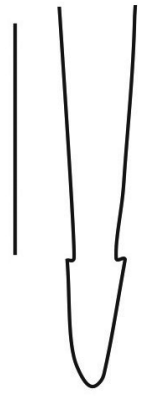

11

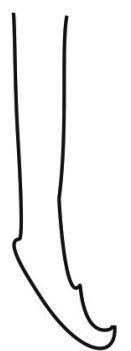

12

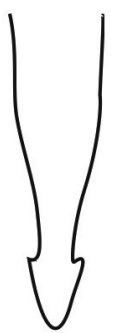

13

Figures I0-13. Aedeagal apicale. I0 $N .(X$.$) arcuata sp. n. in lateral view II N .(X$.$) arcuata sp. \mathrm{n}$. in dorsal view $\mathbf{I} \mathbf{2}$. (X.) hiromichii in lateral view $\mathbf{3} N$. (X.) hiromichii in dorsal view; (Figures 12-13 from Švihla 1998). Scale bars $=0.5 \mathrm{~mm}$.

\section{Nacerdes (Xanthochroa) hiromichii Švihla, 2004}

Figs $12-13$

Xanthochroa apicalis Kôno, 1932: 141.

Nacerdes (Xanthochroa) apicalis Švihla, 1998: 53.

Nacerdes (Xanthochroa) hiromichii Švihla, 2004: 72; Švihla 2008: 364.

Distribution. China: Taiwan.

\section{Nacerdes (Xanthochroa) potanini Ganglbauer, 1890}

Fig. 4

Xanthochroa potanini Ganglbauer, 1890: 36

Nacerdes (Xanthochroa) potanini Švihla, 1998: 54; Švihla 2008: 364.

Material examined. 1 ( $\mathrm{MHBU}$ ): China, Gansu, Wen County, Huangtuling, alt. $1,505 \mathrm{~m}, 33^{\circ} 00^{\prime} 14.85^{\prime \prime} \mathrm{N}, 1^{\circ} 00^{\prime} 41.55^{\prime \prime E}$, 8.vii.2003, Yi-Bin Ba \& Yang Yu

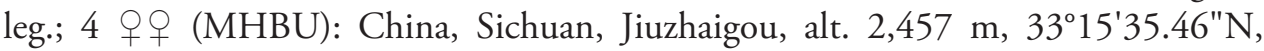
$103^{\circ} 55^{\prime} 06.40$ "E, 7-15.viii.2002, Ming Bai \& Jian-Feng Wang leg.

Distribution. China: Sichuan, Gansu.

\section{Acknowledgements}

We would like to express our sincere thanks to Dr. Mohamed Shebl (Faculty of Agriculture, Suez Canal University), Mrs. Cai-Xia Yuan and Mrs. Shan-Shan Liu (College of Life Sciences, Hebei University) for comments on the manuscript, and many thanks 
are also due to Dr. Yi-Bin Ba (Museum of Hebei University) and Dr. Zhao Pan (Roma Tre University) for kindly help to search literature. The research was supported by the National Natural Science Foundation of China (No. 31272341) and the Foundation of Key Invertebrate Systematics Laboratory in Hebei Province (201309).

\section{References}

Arnett RH (1951) A revision of the Nearctio Oedemeridae (Coleoptera). American Midland Naturalist 45: 257-391. doi: 10.2307/2421732

Arnett RH (1961) Contribution towards a monograph of the Oedemeridae 14. A key to and notes on the New World genera. Coleopterists Bulletin 15: 49-64.

Allemand R (1993) Les Nacerdes Ouest-Palearctiques du sous-genre Xanthochroa Schmidt, notes taxonomiques et commentaires sur la faune francaise (Coleoptera, Oedemeridae). Bulletin de la Societe Entomologique de France 98(1): 5-14.

Dejean PFMA (1834) Catalogue des coléoptères de la collection de M. le Comte Dejean. Deuxième édition. $3^{\mathrm{e}}$ Livraison. Méquignon-Marvis Pères et Fils, Paris, 177-256.

Ganglbauer L (1890) Insecta a Cl. G. N. Potanin in China et in Mongolia novissime lecta. VII. Buprestidae, Oedemeridae, Cerambycidae. Horae Societatis Entomologicae Rossicae 24 [1889-1890]: 21-85.

Kôno H (1932) Die Nacerdinen Japans (Col.). Insecta Matsumurana 6: 138-144.

Švihla V (1983) Contribution to the knowledge of the Palaearctic Oedemeridae (Coleoptera). Entomologica Basiliensia 8: 334-341.

Švihla V (1986) Revision of the generic classification of the Old World Oedemeridae (Coleoptera). Sbornik Narodniho Muzea v Praze Rada B Prirodni Vedy 41(3-4): 141-238.

Švihla V (1987) Contribution to the knowledge of the Old World Oedemeridae (Coleoptera). Annotationes Zoologicae et Botanicae 181: 1-27.

Švihla V (1991) Contribution to the knowledge of the Old World Oedemeridae (Coleoptera). Annotationes Zoologicae et Botanicae 202: 1-14.

Švihla V (1993) Contribution to the knowledge of the Palaearctic Oedemeridae (Coleoptera). Folia Heyrovskyana 1(6): 52-55.

Švihla V (1996) Contribution to the knowledge of the Old World Oedemeridae (Coleoptera). Sbornik Narodniho Muzea v Praze Rada B Prirodni Vedy 51(1-4): 83-88.

Švihla V (1997) Contribution to the knowledge of the Palaearctic and Oriental Oedemeridae (Coleoptera). Folia Heyrovskyana 5(2): 83-96.

Švihla V (1998) Revision of Nacerdes subgenera Xanthochroa and Asiochroa subgen. n. (Coleoptera: Oedemeridae) from Western and Southern China and adjacent regions. Folia Heyrovskyana 6(2): 49-71.

Švihla V (1999) On the taxonomy and nomenclature of the Palaearctic Oedemeridae (Coleoptera). Acta Societatis Zoologicae Bohemicae 63(3): 379-385.

Švihla V (2001) Revision of the Nacerdes subgenus Xanthochroa (Coleoptera: Oedemeridae) from Malaysia and Indonesia with notes on species from other regions. Folia Heyrovskyana 9(3-4): 217-234. 
Švihla V (2004) Contribution to the knowledge of Old World Oedemeridae (Coleoptera). Acta Societatis Zoologicae Bohemicae 68(1): 61-78.

Švihla V (2005) New species and synonymies in Oedemeridae (Coleoptera) from the Palaearctic and Oriental Regions. Folia Heyrovskyana 13(1-2): 71-80.

Švihla V (2006) On the taxonomy of the Palaearctic and Oriental Oedemeridae (Coleoptera). Casopis Narodniho Muzea Rada Prirodovedna 175(1-2): 1-12.

Švihla V (2008) Oedemeridae. In: Löbl I, Smetana A (Eds) Catalogue of Palaearctic Coleoptera,

Volume 5. Tenebrionoidea. Apollo Books, Stenstrup, 353-369.

Švihla V, Hideo A (2009) New species of the family Oedemeridae (Coleoptera) from SouthEastern Asia. Entomologica Basiliensia 31: 89-99.

Vázquez XA (1993) The Iberian fauna. Volume 5: Coleoptera, Oedemeridae, Pyrochroidae, Pythidae, Mycteridae. Museo Nacional de Ciencias Naturales, 181 pp.

Vázquez XA (2002) European fauna of Oedemeridae (Coleoptera). Argania editio, 179 pp. Vázquez XA (2006) A new subspecies of Nacerdes (Xanthochroa) raymondi (Mulsant \& Godart, 1860) from Majorca Island (Coleoptera: Oedemeridae). Bolleti de la Societat d'Historia Natural de les Balears 49: 39-44.

Yoo IS, Park HC, Kim JI (2008) Taxonomic review of the subfamily Nacerdinae (Coleoptera: Oedemeridae) in Korea. Entomological Research (Seoul) 38(4): 287-298. doi: 10.1111/j.1748-5967.2008.00189.x 